\title{
ИСПОЛЬЗОВАНИЕ БЕЛКОВЫХ МАРКЕРОВ В СЕЛЕКЦИИ НА ЗАСУХОУСТОЙЧИВОСТЬ
}

\author{
Ротарь А.И. *, Комарова Г.Е. **, Ротарь Е.А. *, Боунегру С.В. * \\ *ИР «Порумбень», Порумбень, Республика Молдова \\ **ГАУМ, Кишинэу, Республика Молдова \\ e-mail: ifporumbeni@ rambler.ru, anticamera@uasm.md
}

В настоящее время климатические изменения являются одной из угроз для существования человечества. Непосредственно для нашей страны она выражается в аридизации климата, которая приводит к учащению числа засушливых лет. В связи с этим ИР «Порумбень» был предложен и реализован институциональный проект «Создание алгоритма отбора засухоустойчивых форм кукурузы на основе проведения физиолого-биохимической диагностики в условиях Республики Молдова», главная цель которого создание алгоритма отбора засухоустойчивых генотипов кукурузы и создание на их базе засухоустойчивых гибридов.

При разработке и реализации данного проекта широко применялся метод белковых маркеров. Сейчас основное его применение - это определение биологической чистоты семенного материала, однако, во время реализации проекта, были найдены дополнительные резервы данного метода.

На начальных этапах алгоритма метод белковых маркеров применяется для определения биологической чистоты линий, которые будут тестированы на засухоустойчивость.

Затем данный метод использовался для получения оптимальных гибридных комбинаций, для чего была проведена паспортизация линий и определен коэффициент межлиниарной дистанции зеиновых зон. Используя этот коэффициент подбираются оптимальные комбинации засухоустойчивых линий.

На последнем этапе метод белковых маркеров используется для определения степени гибридности семян полученных гибридов с целью получения объективных данных полевых опытов.

Таким образом, использование метода белковых маркеров в «алгоритме создания гибридов кукурузы для богарного семеноводства», являющимся результатом реализации институционального проекта «Создание алгоритма отбора засухоустойчивых форм кукурузы на основе проведения физиолого-биохимической диагностики в условиях Республики Молдова», позволяет получить объективные данные по тестированию линий и гибридов на засухоустойчивость, что, в свою очередь, позволяет объективно оценить тестируемые линии, сократить время создания гибридов и сократить площади экспериментальных участков. 